\title{
Isolation and Identification of Specific Pathogens, Presence of Antibiotics, Aflatoxins, Pesticide Residues and Industrial Contaminants in Supply Chain of Milk in Selected Coastal Districts of Andhra Pradesh
}

\author{
Appalanaidu Kalla, Sunitha Raju Kutcharlapati, Sai Bramari Gannavarapu, \\ Anitha Layam* \\ Department of Microbiology and Food Science \& Technology, Institute of Science, GITAM University, \\ Visakhapatnam, India \\ Email: layamanitha@gmail.com
}

Received 10 February 2015; accepted 24 April 2015; published 29 April 2015

Copyright (C) 2015 by authors and Scientific Research Publishing Inc.

This work is licensed under the Creative Commons Attribution International License (CC BY).

http://creativecommons.org/licenses/by/4.0/

(c) (i) Open Access

\begin{abstract}
A research study was undertaken to carry out isolation and identification of specific pathogens, presence of antibiotics, aflatoxins, pesticide residues and industrial contaminants in supply chain of milk in selected coastal districts of Andhra Pradesh. The milk is a whole food; it is categorized under perishable foods as it is biologically nutrient liquid that supports the growth of wide variety of microorganisms and is susceptible to spoilage. The quality of milk can be affected by the presence of additional water, detergents, disinfectants, antibiotics, pesticides and pathogens like bacteria, viruses, toxins released by molds such as aflatoxins and heavy metals etc. The raw milk is usually colonized by pathogens like Campylobacter jejuni, enterohemorrhagic Escherichia. coli, Salmonella typhimurium, Listeria monocytogenes, Staphylococcus aureus and Yersinia enterocoliti$c a$. The milk samples were collected from vendors of East and West Godavari, Visakhapatnam, Vizianagaram and Srikakulam districts. The milk samples were found to be positive for Tetracycline and Beta lactam antibiotics. The Aspergillus flavus was identified and the colonies producing aflatoxin M1 appeared in yellow color on the Aspergillus agar (M1127). The pesticides and heavy metals in raw and chilled milk samples were detected by atomic absorption spectrophotometer. The pesticide residues were found in raw and chilled milk samples include Lindane, Endosulfan,
\end{abstract}

${ }^{*}$ Corresponding author.

How to cite this paper: Kalla, A., et al. (2015) Isolation and Identification of Specific Pathogens, Presence of Antibiotics, Aflatoxins, Pesticide Residues and Industrial Contaminants in Supply Chain of Milk in Selected Coastal Districts of Andhra Pradesh. Advances in Bioscience and Biotechnology, 6, 330-344. http://dx.doi.org/10.4236/abb.2015.64032 
Chlorane, Heptachlor and Methoxchlor. The heavy metals like lead, arsenic, zinc and mercury residues were found to occur in raw and chilled milk samples. The hygienic quality of the milk in the current study was found to be poor due to exceeding the standard limits in number of specific pathogens, antibiotic, aflatoxin M1, pesticide and heavy metal residues. Immediate measures are needed to be taken to ensure safety of raw milk in public point of view in Visakhapatnam, East \& West Godavari regions.

\section{Keywords}

Aflatoxin M1, Industrial Contaminants, Specific Pathogens

\section{Introduction}

Milk is the complete food composed of higher solid contents such as lipids, proteins, milk sugar (lactose) and minerals. It is rich in vitamins A and B and is an important source of dietary Calcium and other minerals. Milk is much important food source for its chemical composition and nutritive properties. All types of milks are more or less similar in composition and nutritive properties irrespective of their source like cow, buffalo, goat and camel etc. The major constituents of milk are higher in buffalo milk than in cow, goat, camel and human milks [1].

High amounts of protein, medium chain fatty acids, retinol and tocopherol are rich in buffalo milk than in cow milk. Most of the milks contain $80 \%$ of casein and $20 \%$ of whey proteins [2]. The fat content of milk is of much importance and it is rich in buffalo milk than in cow milk. The fat content of milk depends on type of breed, lactating stage, season and live stock feed [3]. Milk sugar lactose is rich carbohydrate found with some variations in content in different kinds of milk obtained from different live stocks [4]. The macro and micro elements found in milk are much important because they influence the degree of intestinal absorption, transport and cellular assimilation or bioavailability [5]. The vitamin content of milk such as carotenes and vitamin A vary with seasonal changes and feed of live stock [6].

Milk production is much related to agriculture because the farmers rear the live stocks in villages. Though dairying associated with agriculture, milk is consumed by only rich sector of people and consumption of milk is a nightmare for poor section of people and hence results in undernourishment or malnutrition. India is the largest producer of milk and accounts for more than $13 \%$ of milk production.

Prior to year 2000, India is neither importer nor exporter of the milk and dairy products, but after 2003, India is one of the fastest growing exporters of dairy products in the world. The National Dairy Development Board has been established in 1965 to draw up the National Dairy Plan [7]. To meet the demands of the middle class population in the country the dairy sector in India proposed spectacular growth which is known as operation flood era. To support the program, almost about ten million farmers were enrolled as members in 73,000 milk cooperative societies in India [7]. The cooperative dairy societies have greatly contributed to the betterment of economic status of people in the villages and hill areas where the dairy industry is most prevalent and chief source of income [7].

The most important function monitored by the dairy cooperatives includes the maintenance and assurance of quality of the milk. The quality system defines all the operations and specifies the setting up the parameters like temperature maintained during the production process and frequency of cleaning the equipments. The safety and hygiene measures like disinfection of production area and handling equipment; personal hygiene of employees are compulsorily taken care to avoid the contamination. The shelf life of the final product is most important because it is the period between the manufacture and the consumption. The milk is the product having only a limited shelf life [8].

As said above, though milk is a whole food, it is categorized under perishable foods as it is biologically nutrient liquid that supports the growth of wide variety of microorganisms and is susceptible to spoilage. The quality of milk can be affected by the presence of undesirable substances like additional water, detergents and disinfectants, antibiotics, pesticides and pathogens like bacteria, viruses and toxins released by molds such as aflatoxins and heavy metals etc.

The milk is the ideal growth medium for several types of microorganisms [9]. Salmonella is the chief causa- 
tive agent of much of the milk borne out breaks and epidemics. The bacteriological quality of milk is the important factor to be considered for the consumption of milk and other dairy products [10]. The raw milk is usually colonized by pathogens like Campylobacter jejuni, enterohemorrhagic E. coli, Salmonella typhimurium, Listeria monocytogenes, Staphylococcus aureus and Yersinia enterocolitica. The pathogens may enter the good quality milk when they are mixed with mastitis milk from the live stock. The pathogen E. coli is a common inhabitant of intestines of animals and gain access to the milk and the diary products. Staphylococcus aureus enters the milk through the mastitis infection of the cattle.

Contaminants other than pathogens found in milk include the antibiotics, pesticides, aflatoxins and heavy metals etc. When the animal is suffering from Mastitis (udder infection) it is treated with Antibiotic infusion in the udder through the teats. As per norms, once the animal is treated with antibiotic infusion for mastitis, milk should not be used for 4 days after the animal is cured, as the residue of antibiotic will be there in the milk [11]. Roca et al. (2011) emphasize that antibiotics are a serious health hazard as they are not completely destroyed by boiling or pasteurization. Evidence indicates that consumption of milk that has antibiotic residues is harmful because it may result in development of drug resistant pathogens, and may also result in allergic reactions [12].

When the animal is fed with feed that is fungal (aflatoxin) infected, it will get excreted in the milk. This should not be present in the milk as per World Health Organization Standard. When such milk is consumed it will act like a cumulative poison and it will damage the liver and cause cirrhosis [13].

Lead is the heavy metal contaminant often found in the milk and if lead in milk is consumed it will cause cancer. The pesticide residues enter milk through the fodder fed to the live stock. Pesticides are often used for the cultivation of cattle fodder to avoid crop infections. Cattle fed with fodder containing high amounts of pesticides secrete them in milk. The objective of present study is to isolate and identify the specific pathogens and other contaminants in supply chain of milk in selected coastal districts of Andhra Pradesh.

\section{Methodology}

\subsection{Source and Collection of Samples}

Milk samples were collected directly from the farmers (producers supplying the milk to the dairies) bulk chilling centers and pasteurized milk and vendor's milk around the Coastal Districts of AP in INDIA.

A total of 600 samples of $100 \mathrm{ml}$ volume were collected. Milk samples were aseptically collected using 100 $\mathrm{ml}$ sterilized Duran screw capped bottles. The samples were labeled with the name of the sources after collection. Milk samples were transported to the laboratory in an ice-cooling box (container) maintained at temperature lower than $5^{\circ} \mathrm{C}$ and in the laboratory, the samples were stored in a refrigerator at temperatures lower than $5^{\circ} \mathrm{C}$. Laboratory analysis was done within 24 hrs of collection.

\subsection{Isolation and Enumeration of Specific Pathogens from Milk Samples}

Specific pathogens can be isolated by using streak plate method by using enrichment and selected media and identification kits, conformation tests as described by Hi media, Mumbai India private limited.

\subsubsection{Identification of E. coli Species}

Presence of pathogens in milk samples can be detected by the use of streak plate method on Eosin methylene blue agar (EMB Agar m317). Samples were incubated at $37^{\circ} \mathrm{C}$ for $24 \mathrm{hrs.}$

\subsubsection{Identification of Salmonella and Shigella spp.}

The milk samples are streaked on to Brilliant green agar and SS agar for the identification of Salmonella and Shigella spp. respectively.

\subsubsection{Identification of Listeria}

The milk samples are streaked on LPM Hi veg agar base (MV1228) for the identification of Listeria spp.

\subsection{Standard Plate Count of Pathogens}

The standard plate count or total bacterial count was determined by using the spread plate method on Tryptone glucose yeast extract agar (M014) Hi media Mumbai India pvt ltd. Sample dilution was done in phosphate buf- 
fer solution. The inoculated plates were incubated at $37^{\circ} \mathrm{C}$ for $48 \mathrm{hrs}$. After incubation, the number of colonies was counted by using Lapiz colony counter (S. No. 0671, A.090) and expressed as cfu/ml (colony forming unit per $\mathrm{ml})$.

\subsection{Detection of Antibiotics Residues}

Antimicrobial residues were detected by Delvotest and beta-lactam and Tetracycline rapid test kit method. In the Delvotest the presence of drug residues in milk can be detected by kit providing ampoules with embedded media containing Bacillus stearothermophilus var calidolactis and then they are incubated in water bath for 2 - 30 hrs at $64^{\circ} \mathrm{C}$.

Beta Lactam and Tetracycline Rapid Test

Kit detection method was used to detect for rapid qualitative analysis of beta-lactam and tetracycline antibiotics in milk samples. In this test, micro wells and strips were used and the test was based on the specific reaction of Antigen-Antibody, and immuno chromatography. Strip was dipped into well which contains milk and kept for 5 minutes at room temperature (Rapid kit-Beijing-YF-marisglobalco, China).

\subsection{Detection of Aflatoxin M1}

Aflatoxin M1 was detected by using the ELISA (Enzyme linked immune sorbent assay) method and thin layer chromatography technique, and Massspectrometer method. The aflatoxin M1 is produced by Aspergillus flavus spp. and it was identified by streak plated method on selected Aspergillus Agar and incubated at $22^{\circ} \mathrm{C}$ for 3 days, will produce light yellow colored colonies after 3 days at $22^{\circ} \mathrm{C}$.

\subsection{Detection of Pesticide Residues \& Heavy Metals}

Heavy metal residue was detected by using method Atomic Absorption spectrophotometer, and it is approved method by Association of official Analytical Chemist (AOAC), (M1022-01, QPS BIOSERVE INDIA PVT LTD Hyderabad). Pesticide residues were detected by Atomic Absorption spectrophotometer method (M1008-01) at Bhagavathi Ana labs pvt ltd, Hyderabad and CHOKSI laboratories ltd, Indore.

\section{Results and Discussion}

The milk samples were collected from vendors of East and West Godavari, Visakhapatnam, Vizianagaram and Srikakulam districts. The samples were tested for the presence of specific pathogens, antibiotic residues, aflatoxin M1, pesticides and industrial contaminants.

\subsection{Detection of Specific Pathogens}

The pathogens like E. coli, Staphylococcus aureus, Salmonella, Shigella and Listeria were identified on specific media like EMB Agar m317, Mannitol salt agar (M118), Brilliant green agar, SS AGAR (M108) and LPM Hi veg agar base (MV1228) respectively. Only colonies having green metallic sheen colonies observed along with the streak were identified as E. coli.

The golden yellow colored colonies along with streak on Mannitol salt agar (M118) were identified as Staphylococcus aureus. The pink colored colonies appeared on brilliant green agar was identified as Salmonella spp. The pink to colorless colonies observed on SS AGAR (M108) were identified as Shigella spp. Light yellow colored colonies observed on, LPM Hi veg agar base (MV1228) were identified as Listeria spp. The percentage of specific pathogens in raw, chilled and pasteurized milk samples were given in Tables 1-3 respectively.

The specific pathogens in raw milk samples collected from various regions were represented in the Table 1. In Visakha region Staphylococcus aureus was most prevalent and found in $90 \%$ of the samples. E. coli was found in $86 \%$ of the samples and the other pathogens like Salmonella and Shigella were found in $62 \%$ and $20 \%$ of the samples respectively. Listeria was totally absent in raw milk samples of Visakha region. In Srikakulam region Staphylococcus aureus was found to be major contaminant of raw milk samples and was found in $100 \%$ of samples. E. coli was found in $90 \%$ of samples, Salmonella, Shigella and Listeria were found in $70 \%, 40 \%$ and $20 \%$ of samples respectively. In Vizianagaram, $96 \%$ of samples were found to contain Staphylococcus 
Table 1. Specific pathogens present in raw milk.

\begin{tabular}{ccccccc}
\hline Name of the region & No of samples & E. coli & Staphylococcus & Salmonella & Shigella & Listeria \\
\hline Visakha & 50 & $43(86 \%)$ & $45(90 \%)$ & $31(62 \%)$ & $10(20 \%)$ & NIL \\
Srikakulam & 50 & $45(90 \%)$ & $50(100 \%)$ & $35(70 \%)$ & $20(40 \%)$ & $10(20 \%)$ \\
Vizianagaram & 50 & $40(80 \%)$ & $48(96 \%)$ & $30(60 \%)$ & $18(36 \%)$ & $12(24 \%)$ \\
East Godavari & 50 & $45(90 \%)$ & $48(96 \%)$ & $25(50 \%)$ & $10(20 \%)$ & $02(4 \%)$ \\
West Godavari & 50 & $40(80 \%)$ & $45(90 \%)$ & $28(56 \%)$ & $10(20 \%)$ & $04(8 \%)$ \\
Vendors & 50 & $45(90 \%)$ & $45(90 \%)$ & $25(50 \%)$ & $15(30 \%)$ & $04(8 \%)$ \\
\hline
\end{tabular}

Table 2. Specific pathogens present in chilled milk samples.

\begin{tabular}{ccccccc}
\hline Name of the region & No of samples & E. coli & Staphylococcus & Salmonella & Shigella & Listeria \\
\hline Visakhapatnam & 50 & $40(80 \%)$ & $45(90 \%)$ & $25(50 \%)$ & $10(20 \%)$ & $05(10 \%)$ \\
Srikakulam & 50 & $45(90 \%)$ & $48(96 \%)$ & $32(64 \%)$ & $8(16 \%)$ & $08(16 \%)$ \\
Vizianagaram & 50 & $39(78 \%)$ & $45(90 \%)$ & $30(60 \%)$ & $15(30 \%)$ & $10(20 \%)$ \\
East Godavari & 50 & $40(80 \%)$ & $45(90 \%)$ & $20(40 \%)$ & $10(20 \%)$ & $05(10 \%)$ \\
West Godavari & 50 & $42(84 \%)$ & $40(80 \%)$ & $24(48 \%)$ & $20(40 \%)$ & $05(10 \%)$ \\
\hline
\end{tabular}

Table 3. Percentage of specific pathogens in pasteurized milk.

\begin{tabular}{|c|c|c|c|c|c|}
\hline Name of dairy & E. coli & Staph aureus & Shigella & Salmonella & Listeria \\
\hline Agri gold & 40 & 80 & 10 & 20 & 0 \\
\hline Milk line & 40 & 90 & 20 & 40 & 0 \\
\hline Tirumala & 20 & 60 & 20 & 60 & 0 \\
\hline Visakha & 0 & 80 & 20 & 50 & 0 \\
\hline Heritage & 02 & 40 & 0 & 20 & 0 \\
\hline Jersy & 20 & 60 & 20 & 20 & 0 \\
\hline Kamadenu & 80 & 90 & 40 & 50 & 0 \\
\hline
\end{tabular}

aureus and $80 \%$ of sample contained E. coli. The rest of the pathogens were found in $60 \%$, 36\% and $24 \%$ of samples respectively. In East Godavari, Staphylococcus aureus was found in $96 \%$ of the samples and E. coli in $90 \%$ of the samples. The other pathogens were found in $50 \%, 20 \%$ and $4 \%$ of samples respectively. In West Godavari region, $90 \%$ of samples were found to contain Staphylococcus aureus and 80\% of E. coli. Salmonella was found $56 \%$ of the samples, Shigella in $20 \%$ and Listeria was found in $8 \%$ of samples. In vendor's milk samples Staphylococci and E. coli were most prevalent and were found in $90 \%$ of samples. The other pathogens were found in 50\%, 30\% and 8\% of samples respectively. These results can also be observed from Figure 1.

The specific pathogens in chilled milk samples collected from various regions were represented in the Table 2. In Visakha region Staphylococcus aureus was most prevalent and found in $90 \%$ of the samples. E. coli was found in $80 \%$ of the samples and the other pathogens like Salmonella and Shigella were found in 50\% and 20\% of the samples respectively. Listeria was found in $10 \%$ of the samples. In Srikakulam region Staphylococcus aureus was found to be major contaminant of chilled milk samples and was found in $96 \%$ of samples. E. coli was found in $90 \%$ of samples, Salmonella, Shigella and Listeria were found in 64\%, 16\% and 16\% of samples respectively. In Vizianagaram, 90\% of samples were found to contain Staphylococcus aureus and 78\% of sample contained E. coli. The rest of the pathogens were found in $60 \%, 30 \%$ and $20 \%$ of samples respectively. In East Godavari, Staphylococcus aureus was found in $90 \%$ of the samples and E. coli in $80 \%$ of the samples. The other pathogens were found in $40 \%, 20 \%$ and $10 \%$ of samples respectively. In West Godavari region, $80 \%$ of samples were found to contain Staphylococcus aureus and $84 \%$ of E. coli. Salmonella was found $48 \%$ of the samples, Shigella in $40 \%$ and Listeria was found in $10 \%$ of samples. 


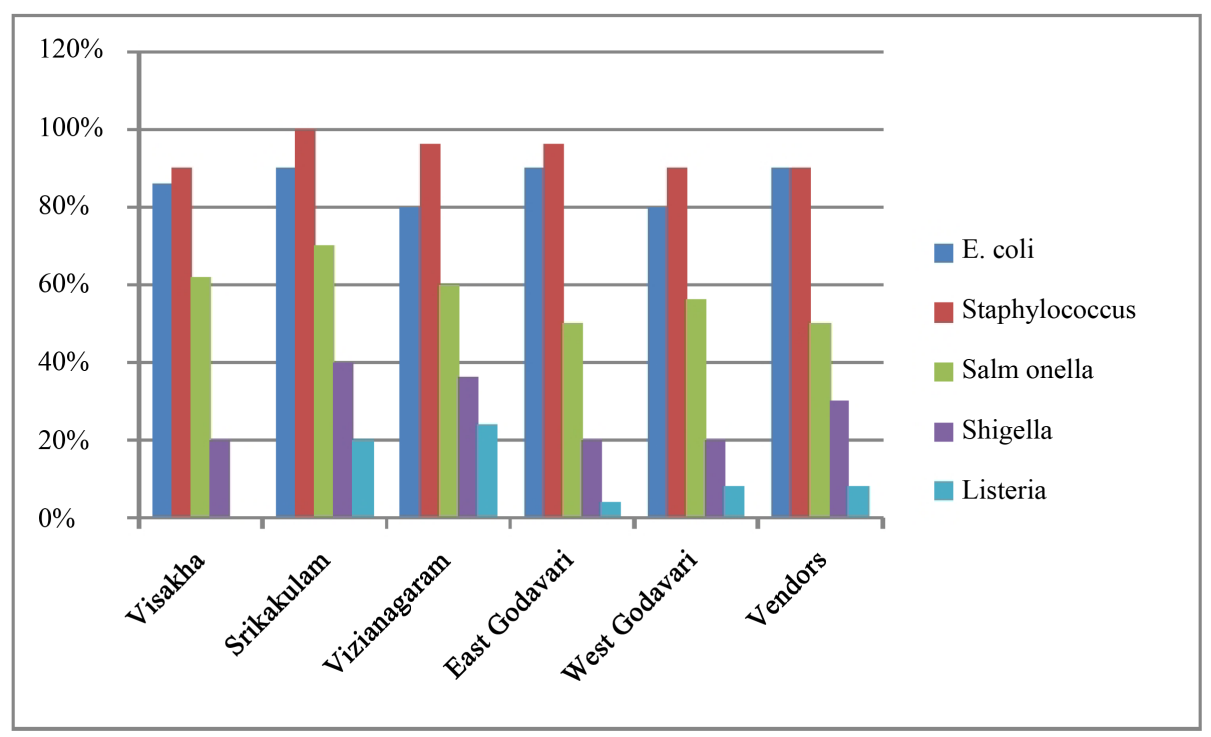

Figure 1. Percent of specific pathogens isolated from raw and vendor's milk samples in different regions.

The specific pathogens in pasteurized milk samples collected from various regions were represented in the Table 3. In Agri Gold diary milk samples Staphylococcus aureus was most prevalent and found in $80 \%$ of the samples. E. coli was found in $40 \%$ of the samples and the other pathogens like Salmonella and Shigella were found in $20 \%$ and $10 \%$ of the samples respectively. Listeria was totally absent in pasteurized milk samples of Agri gold diary. In Milk Line diary milk samples Staphylococcus aureus was found in $90 \%$ of samples. E. coli was found in $40 \%$ of samples, Salmonella and Shigella were found in $40 \%$, $20 \%$ of samples respectively. In Tirumala diary milk samples, $60 \%$ of samples were found to contain Staphylococcus aureus and $20 \%$ of sample contained E. coli. The rest of the pathogens were found in $60 \%, 20 \%$ samples respectively. In Visakha diary milk samples, Staphylococcus aureus was found in $80 \%$ of the samples and E. coli in $20 \%$ of the samples. The other pathogens were found in $50 \%, 20 \%$ of samples respectively. In Heritage diary milk samples, $60 \%$ of samples were found to contain Staphylococcus aureus and 20\% of E. coli. Salmonella was found $20 \%$ of the samples, Shigella in $20 \%$ of samples. In Jersy dairy milk samples Staphylococci and E. coli were found in $60 \%, 20 \%$ of samples respectively. The other pathogens were found in $20 \%, 20 \%$ of samples respectively. In Kamadhenu diary milk $90 \%$ of samples were found to contain Staphylococcus aureus and $80 \%$ of E. coli. Salmonella was found in $50 \%$ of the samples, Shigella in $40 \%$ of samples. Both the Milk line and Kamadhenu milk samples were found to contain high percentage of S. aureus (90\%). The contamination possibility is there after pasteurization and can be caused by packing machines, packaging material and water used for washing the machines and other purposes. The quality of these milk samples is judged as poor because of the presence of specific pathogens that cause various types of illness in the consumers.

Contamination of pasteurized milk can occur through unhygienic pipelines, packing machines and packaging materials and also through non-sterile environment. Specific pathogenic bacteria were found in pasteurized milk samples from various regions in coastal districts belong to private and semi government sector dairies. Most of the samples were found to be positive for E. coli and Salmonella \& Shigella. Similar results of pathogens in raw milk (57\% of E. coli and 38\% of S. aureus in cow milk) of different live stock were obtained by Ekici, et al., (2004) [14]. The pathogens like E. coli (36.66\%) and Staphylococcus aureus (56.66\%) were isolated from raw milk samples in Egypt [15].

\subsection{Enumeration of Pathogens by Standard Plate Count}

The standard plate count or total bacterial count was determined by using the spread plate method on Tryptone glucose yeast extract agar (M014) Hi media Mumbai India pvt ltd. After incubation, the number of colonies was counted using the Lapiz colony counter (S. No. 0671) and the results were tabulated. The standard plate counts were expressed as $\mathrm{cfu} / \mathrm{ml}$. The standard plate counts of raw, chilled and pasteurized milk samples were shown in 
Table 4 and in Figure 2.

The results of standard plate count in raw, chilled, and pasteurized and vendor's milk samples were shown in Table 4. In Visakhapatnam, the average number of colonies found in raw milk samples was about $4.8 \times 10^{6}$ $\mathrm{cfu} / \mathrm{ml}, 4.5 \times 10^{6} \mathrm{cfu} / \mathrm{ml}$ were found in chilled milk and $3.8 \times 10^{6} \mathrm{cfu} / \mathrm{ml}$ were present in pasteurized milk and $5.8 \times 10^{6} \mathrm{cfu} / \mathrm{ml}$ in vendor's milk samples respectively. In Vizianagaram, the average numbers of colonies found in raw milk samples were about $5.0 \times 10^{6} \mathrm{cfu} / \mathrm{ml}$ and $4.8 \times 10^{6} \mathrm{cfu} / \mathrm{ml}$ were found in chilled milk and $4.5 \times 10^{6}$ $\mathrm{cfu} / \mathrm{ml}$ were present in pasteurized milk samples. In Srikakulam region, the average number of colonies found in raw milk samples was about $6.5 \times 10^{6} \mathrm{cfu} / \mathrm{ml}$, chilled milk contained $5.0 \times 10^{6} \mathrm{cfu} / \mathrm{ml}$ and $4.0 \times 10^{6} \mathrm{cfu} / \mathrm{ml}$ were present in pasteurized milk samples. In East Godavari region, the average number of colonies found in raw milk samples were about $5.8 \times 10^{6} \mathrm{cfu} / \mathrm{ml}, 6.2 \times 10^{6} \mathrm{cfu} / \mathrm{ml}$ in chilled milk; $4.0 \times 10^{6} \mathrm{cfu} / \mathrm{ml}$ in pasteurized milk samples. In West Godavari, the average number of colonies found in raw milk samples were about $6.0 \times 10^{6} \mathrm{cfu} / \mathrm{ml}$, $4.8 \times 10^{6} \mathrm{cfu} / \mathrm{ml}$ in chilled milk; $4.0 \times 10^{6} \mathrm{cfu} / \mathrm{ml}$ in pasteurized milk samples.

The microbiological and chemical analysis of raw, pasteurized and UHT (ultra high temperature) milk was carried out by Monika saxena and Poonam Rai in 2013 indicated presence of coliform bacteria in high counts $(2.23 \pm 0.10 \mathrm{log} \mathrm{cfu} / \mathrm{ml})$. The coliform bacteria cannot survive at pasteurization temperatures but were found to increase with increased time periods indicating the poor quality of milk in all three conditions (3.37 to $3.48 \pm$ $0.26 \mathrm{log} \mathrm{cfu} / \mathrm{ml})$. The total viable count of raw milk was increased from $4.19 \pm 0.69$ to $6.35 \pm 0.11 \mathrm{log} \mathrm{cfu} / \mathrm{ml}$. In pasteurized milk initial counts were $3.43 \pm 0.17$ to $4.82 \pm 0.05 \mathrm{log} \mathrm{cfu} / \mathrm{ml}[16]$.

Table 4. Standard plate count in raw milk, chilled milk, pasteurized and vendor's milk in different regions of AP.

\begin{tabular}{ccccc}
\hline Name of the region & $\begin{array}{c}\text { Total number of } \\
\text { samples }\end{array}$ & $\begin{array}{c}\mathrm{Cfu} / \mathrm{ml} \mathrm{in} 10^{-5} \text { in raw } \\
\text { milk }\end{array}$ & $\begin{array}{c}\text { Cfu/ml in } 10^{-5} \text { in } \\
\text { chilled milk }\end{array}$ & $\begin{array}{c}\mathrm{Cfu} / \mathrm{ml} \mathrm{in} 10^{-5} \text { in } \\
\text { pasteurized milk }\end{array}$ \\
\hline Visakhapatnam & 50 & 48 & 45 & 38 \\
Vizianagaram & 50 & 50 & 48 & 45 \\
Srikakulam & 50 & 65 & 50 & 40 \\
East Godavari & 50 & 58 & 48 & 40 \\
West Godavari & 50 & 60 & 58 & - \\
Vendor's milk & 50 & & & 40 \\
\hline
\end{tabular}

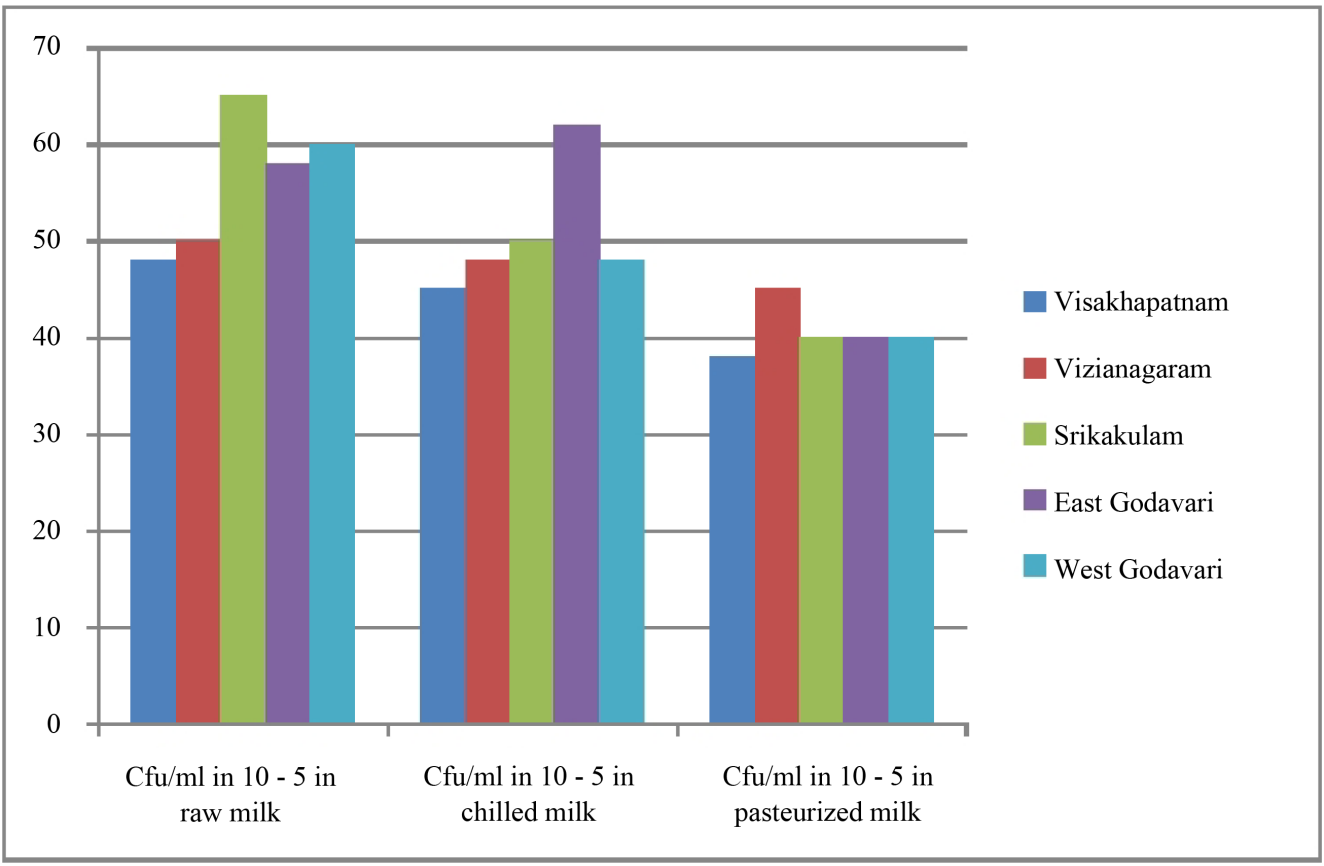

Figure 2. Number of cfu/ml in raw milk, chilled milk, and pasteurized milk in different regions. ${ }^{*} \mathrm{Cfu} / \mathrm{ml}$ in $10^{-5}$. 


\subsection{Detection of Beta Lactam and Tetracycline Antibiotics in Milk Samples by Kit Method}

The milk samples were subjected to Delvo test to detect antibiotic resides in milk samples. The color change in milk samples indicates presence or absence of antibiotic residue in the milk sample. The milk samples turn into purple color in presence of antibiotic residues and yellow color in absence of antibiotic residues in milk samples. The milk samples positive for Tetracycline can be detected by observing no color change in T-line and milk sample positive for Beta lactam positive can be detected by observing no color change in B-line. The number of positive samples for presence of antibiotic residues in raw and chilled milk was shown in Table 5.

The Penicillin-G was found in $4 \%$ of milk samples in Visakha, Vizianagaram, East Godavari, and West Godavari and in Vendor's milk samples but only in $2 \%$ of samples in Srikakulam region. Tetracycline was found in 2\% of samples in Visakha, Srikakulam, Vizianagaram, East and West Godavari districts and in 6\% of samples of vendor's milk. The Oxytetracycline residues were found in $4 \%$ of samples in Visakhapatnam and east Godavari regions. In Srikakulam, Vizianagaram and West Godavari 2\% of samples contained the Oxytetracycline residues and $6 \%$ of samples of vendor's milk were positive for the Oxytetracycline residues.

Most of the antimicrobial substances such as Penicillin-G and Oxytetracycline are used for treating mastitis in cattle. It is normal that lactating cow and buffaloes which are occasionally treated for diseases using veterinary pharmaceuticals particularly if mastitis occur residues of medicines are secreted in the milk by the organism of the animal (The antibiotics normally used are legally registered veterinary pharmaceutical drugs to treat milk producing animals. These contain information about the drug withdrawal period and this information to the end users is a mandatory. The post administration within which human consumption of the treated animals or its product is safe or unsafe or prohibited must be given on the label).

The results of the current study were similar to the detection of antibiotic residues in raw milk samples in Freha area of Algeria. The raw milk samples have shown the high amounts of antibiotics than the recommended values and indicate high contamination of raw milk samples and bad veterinary practices [17]. The antibiotic residues were also found in fresh raw milk samples analyzed in Bangladesh. According to Food and Agricultural Organization (FAO) and European Union the maximum residual limit (MRL) is set as $100 \mathrm{ng} / \mathrm{ml}$ for safe level of consumption. Residues of antibiotics more than $100 \mathrm{ng} / \mathrm{ml}$ are considered as hazardous to health [18].

In chilled milk, the Penicillin-G was found in $2 \%$ of milk samples in Visakha and East Godavari. In Srikakulam and West Godavari 1\% of milk samples were positive for Penicillin-G. In Vizianagaram, $10 \%$ of chilled milk samples contained Penicillin-G. Tetracycline was found in $4 \%$ of samples in Visakha, Vizianagaram, and West Godavari districts and in 2\% of samples of Srikakulam and East Godavari regions. The Oxytetracycline residues were found in 2\% of samples in Visakhapatnam and Srikakulam, 8\% samples were positive for oxytetracycline in Vizianagaram. In East and West Godavari 4\% of samples contained the Oxytetracycline residues. The antibiotic residues found in the pasteurized milk samples were also in high levels than recommended in West Azerbaijan province of North West Iran. The antibiotic residues cannot be destroyed by pasteurization temperatures and high percentages of residues cause severe health problems to consumers [19].

\subsection{Detection of Aflatoxin M1}

The Aspergillus flavus was identified when the sample was streaked on Aspergillus agar. The colonies appeared

Table 5. Percent positive samples for antibiotic residues in raw and chilled milk.

\begin{tabular}{|c|c|c|c|c|c|c|c|}
\hline \multirow{2}{*}{ Name of the region } & \multirow{2}{*}{$\begin{array}{l}\text { Total number } \\
\text { of samples }\end{array}$} & \multicolumn{2}{|c|}{ Penicillin-G } & \multicolumn{2}{|c|}{ Tetracycline } & \multicolumn{2}{|c|}{ Oxy tetracycline } \\
\hline & & Raw & Chilled & Raw & Chilled & Raw & Chilled \\
\hline Visakhapatnam & 50 & 4 & 4 & 2 & 4 & 4 & 2 \\
\hline Srikakulam & 50 & 2 & 2 & 2 & 2 & 2 & 2 \\
\hline Vizianagaram & 50 & 4 & 10 & 2 & 4 & 2 & 8 \\
\hline East Godavari & 50 & 4 & 4 & 1 & 2 & 4 & 4 \\
\hline West Godavari & 50 & 4 & 2 & 2 & 4 & 2 & 4 \\
\hline Vendors & 50 & 4 & nd & 6 & nd & 6 & nd \\
\hline
\end{tabular}

*nd: not detected. 
in yellow color on the Aspergillus agar (M1127). The percent of raw and chilled milk samples positive for aflatoxin M1 was shown in Table 6 in the Figure 3.

The number of positive raw milk samples containing aflatoxin M1 in various regions was shown in Table 6. In Visakhapatnam region, 20\% of raw milk samples contained aflatoxin M1. Very high percent of positive samples (60\%) were found in Srikakulam and East Godavari regions and also in vendor's milk samples. In Vizianagaram, $50 \%$ and in West Godavari $40 \%$ of samples were positive for Aflatoxin M1. The number of positive chilled milk samples containing aflatoxin M1 in various regions was shown in Table 6. In Visakhapatnam region, $20 \%$ of chilled milk samples contained aflatoxin M1. About $50 \%$ of positive samples were found in Srikakulam and East Godavari. In Vizianagaram, 40\% and in West Godavari 36\% of samples were positive for aflatoxin M1.

The presence of aflatoxin M1 affects the quality of the milk. The live stock feeding on fodder containing aflatoxin B produce milk containing aflatoxin M1 ranging from 1.05 to $10.58 \mathrm{ng} / \mathrm{lit}$. The aflatoxin B undergoes biotranformation and hydroxylated to form aflatoxin M1. The increase in the aflatoxin residue in milk samples was found to be much higher in early lactation than in late lactation [12] [20] [21]. The aflatoxin M1 was also found in milk samples collected from dairy cattle of Khatorum state of Sudan. The aflatoxin M1 residues were identified by using ELISA method. As many as $98.6 \%$ of samples were detected with aflatoxin M1 residues and contain the residues maximum than the tolerance level (50 ng/lit) [13].

\subsection{Detection of Heavy Metals and Pesticides in Milk Samples}

The pesticides and heavy metals in raw and chilled milk samples were detected by atomic absorption spectro

Table 6. Percent of positive samples of raw and chilled milk samples for aflatoxin M1.

\begin{tabular}{cccc}
\hline Name of the region & Total no. of samples & Raw milk & Chilled milk \\
\hline Visakha & 50 & 20 & 20 \\
Srikakulam & 50 & 60 & 50 \\
Vizianagaram & 50 & 50 & 40 \\
East Godavari & 50 & 60 & 50 \\
West Godavari & 50 & 60 & 36 \\
Vendors & 50 & nd \\
\hline
\end{tabular}

${ }^{*}$ nd: not detected.

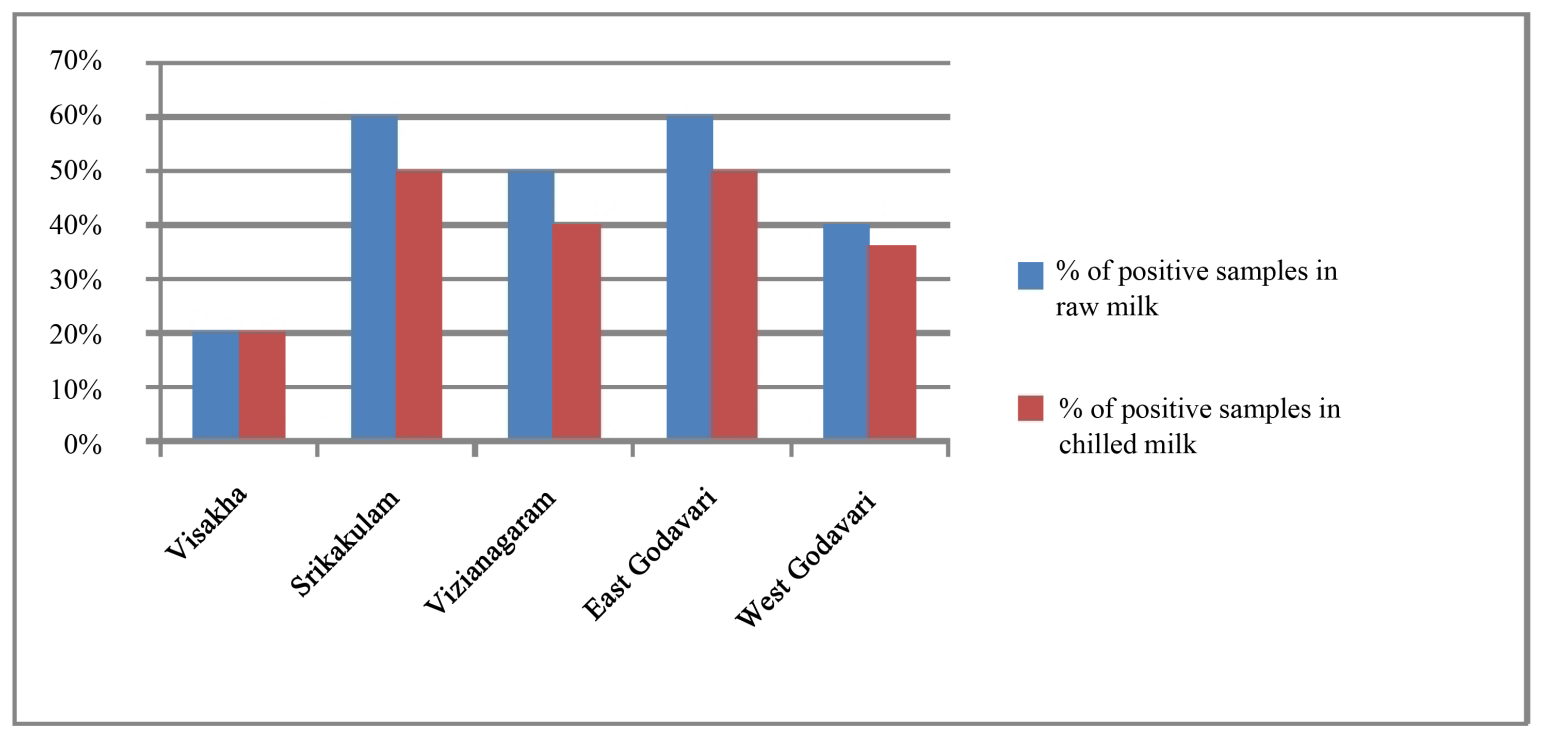

Figure 3. Percent of positive raw and chilled milk samples for aflatoxin M1 in different regions. 
photometer. The number of raw milk samples positive for presence of pesticides was shown in Table 7 and chilled milk samples were shown Table 8 . The percent of raw and chilled milk samples containing pesticide residues were shown in Figure 4 and Figure 5 respectively. The number of raw milk and vendor's milk samples positive for presence of heavy metals were shown Table 9 and chilled milk samples were shown in Table 10. The percent of raw and chilled milk samples containing heavy metals were shown in Figure 6 and Figure 7 respectively.

The pesticide residues were found in raw milk samples includes Lindane, Endosulfan, Chlorane, Heptachlor

Table 7. Percentage of positive samples for pesticide residues in raw milk.

\begin{tabular}{cccccccc}
\hline Name of pesticide & $\begin{array}{c}\text { Total no. of } \\
\text { samples }\end{array}$ & Visakha & Srikakulam & Vizianagaram & East Godavari & $\begin{array}{c}\text { Weat } \\
\text { Godavari }\end{array}$ & Vendors \\
\hline Lindane & 50 & 20 & 40 & 40 & 50 & 50 & 40 \\
Endosulfan & 50 & 40 & 50 & 46 & 40 & 46 & 50 \\
Chlorane & 50 & 20 & 40 & 36 & 34 & 40 & 40 \\
Heptachlor & 50 & 40 & 46 & 40 & 30 & 36 & 50 \\
Methoxchlor & 50 & 20 & 40 & 36 & & 50 & 56 \\
\hline
\end{tabular}

Table 8. Percentage of positive samples for pesticide residues in chilled milk.

\begin{tabular}{|c|c|c|c|c|c|c|}
\hline $\begin{array}{l}\text { Name of the } \\
\text { pesticide }\end{array}$ & $\begin{array}{l}\text { Total number of } \\
\text { samples }\end{array}$ & Visakha & Srikakulam & Vizianagaram & East Godavari & West Godavari \\
\hline Lindane & 50 & 20 & 36 & 38 & 48 & 50 \\
\hline Endosulfan & 50 & 40 & 48 & 46 & 38 & 44 \\
\hline Chlorane & 50 & 20 & 40 & 34 & 34 & 36 \\
\hline Heptachlor & 50 & 22 & 42 & 38 & 28 & 24 \\
\hline Methoxchlor & 50 & 20 & 40 & 36 & 38 & 50 \\
\hline
\end{tabular}

Table 9. Percent of heavy metals in raw milk of different regions.

\begin{tabular}{|c|c|c|c|c|c|}
\hline Name of the region & Total no. of samples & Lead & Arsenic & Zinc & Mercury \\
\hline Visakha & 50 & 20 & 40 & 80 & 10 \\
\hline Srikakulam & 50 & 04 & 0 & 40 & 0 \\
\hline Vizianagaram & 50 & 04 & 0 & 50 & 0 \\
\hline East Godavari & 50 & 02 & 0 & 30 & 0 \\
\hline West Godavari & 50 & 02 & 0 & 30 & 0 \\
\hline Vendors & 50 & 40 & 30 & 80 & 02 \\
\hline
\end{tabular}

Table 10. Percent of heavy metals in chilled milk of different regions.

\begin{tabular}{cccccc}
\hline Name of the region & Total no of samples & Lead & Arsenic & Zinc & Mercury \\
\hline Visakha & 50 & 10 & 16 & 0 & 70 \\
Srikakulam & 50 & 02 & 0 & 48 & 0 \\
Vizianagaram & 50 & 02 & 0 & 30 & 0 \\
East Godavari & 50 & 02 & 0 & 30 & 0 \\
West godavari & 50 & & 02 & 0 \\
\hline
\end{tabular}




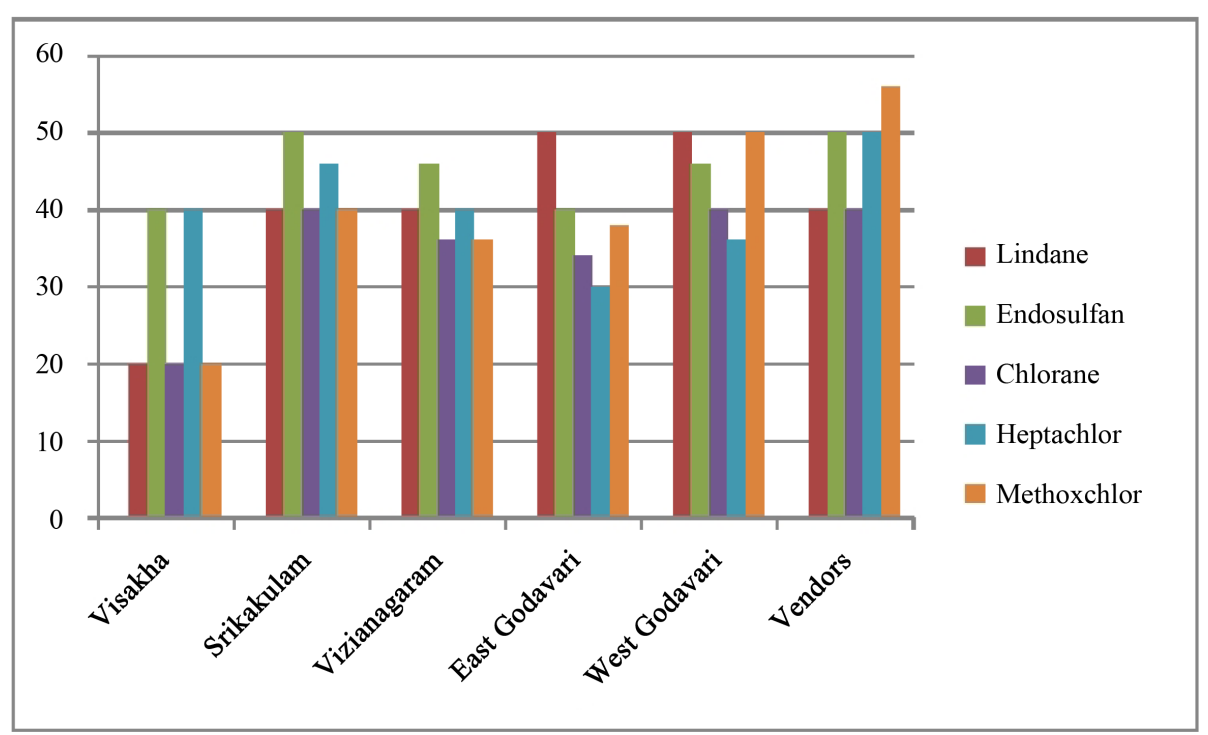

Figure 4. Percent of positive raw milk samples for pesticide residues in different regions.

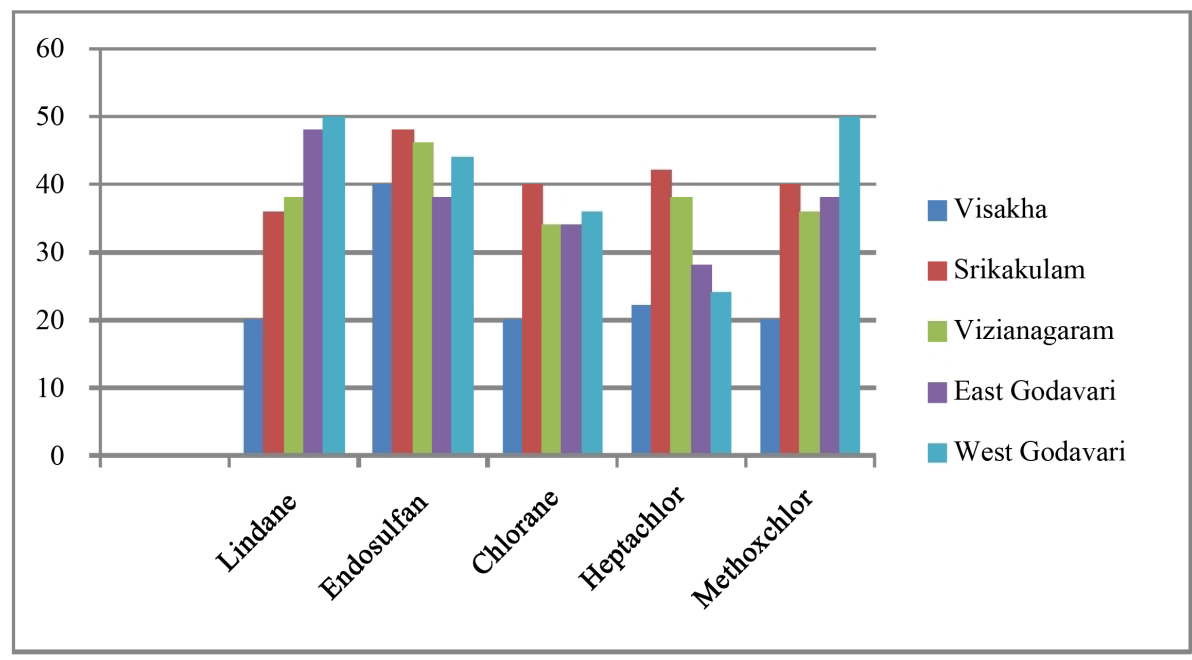

Figure 5. Percent of positive chilled milk samples for pesticide residues in different regions.

and Methoxchlor. The percentage of positive raw milk samples in various regions were shown in Table 7. In Visakhapatnam, Lindane, Chlorane and Methoxchlor were found in 20\%, Endosulfan and Heptachlor were found in $40 \%$ samples. In Srikakulam, Lindane, Chlorane and Methoxchlor were found in $40 \%$ of samples. About $50 \%$ of samples were positive for Endosulfan and $46 \%$ of samples positive for Heptachlor. In Vizianagaram, $40 \%$ of samples were positive for Lindane and Heptachlor. About 36\% of samples were positive for Chlorane and Mehtoxchlor. Endosulfan was found in $46 \%$ of samples. In East Godavari, $50 \%$ of samples contained Lindane, $40 \%$ of samples contained Endosulfan, $34 \%$ of samples contained Chlorane and 30 and $38 \%$ samples were positive for Heptachlor and Methoxchlor respectively. In West Godavari, 50\% of samples were positive for Lindane and Methoxchlor, Endosulfan was present in $46 \%$ of samples, Chlorane was present in $40 \%$ of samples and $36 \%$ of samples contained Heptachlor. In vendor's milk samples, $40 \%$ of Lindane, Chlorane, $50 \%$ of Endosulfan and Heptachlor and $56 \%$ of samples were positive for Methoxchlor.

The pesticide residues were found in chilled milk samples includes Lindane, Endosulfan, Chlorane, Heptachlor and Methoxchlor. The percentage of positive chilled milk samples in various regions were shown in Table 8. In Visakhapatnam, Lindane, Chlorane and Methoxchlor were found in 20\%, Endosulfan in $40 \%$ and Heptachlor in $22 \%$ of samples. In Srikakulam, Lindane was found in $36 \%$ of samples. 


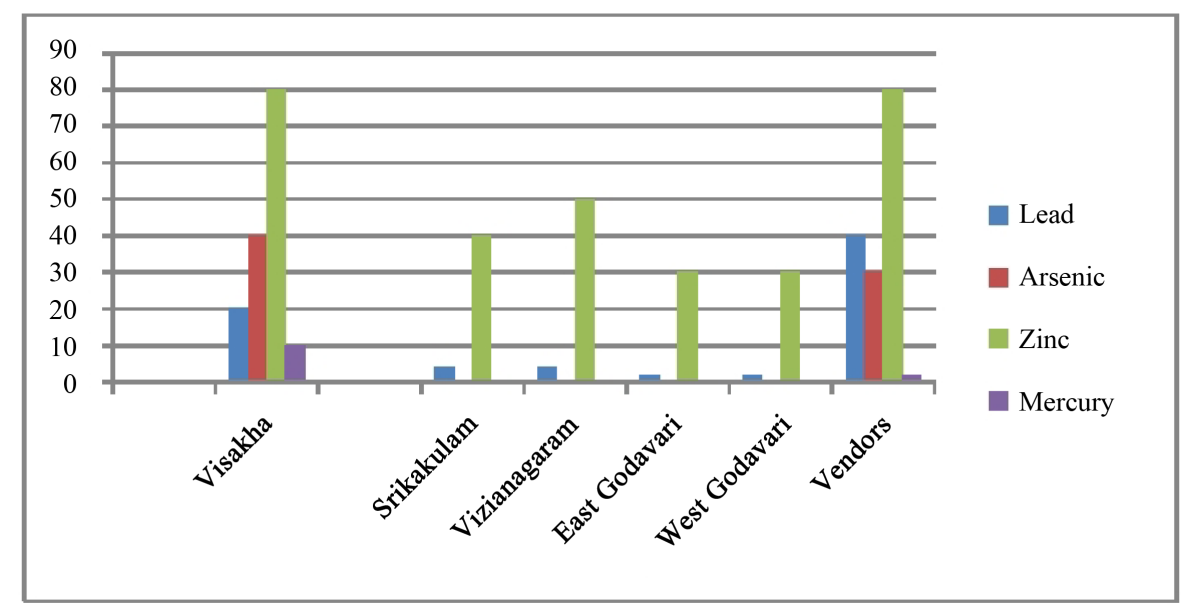

Figure 6. Percent of positive raw milk samples for heavy metals in different regions.

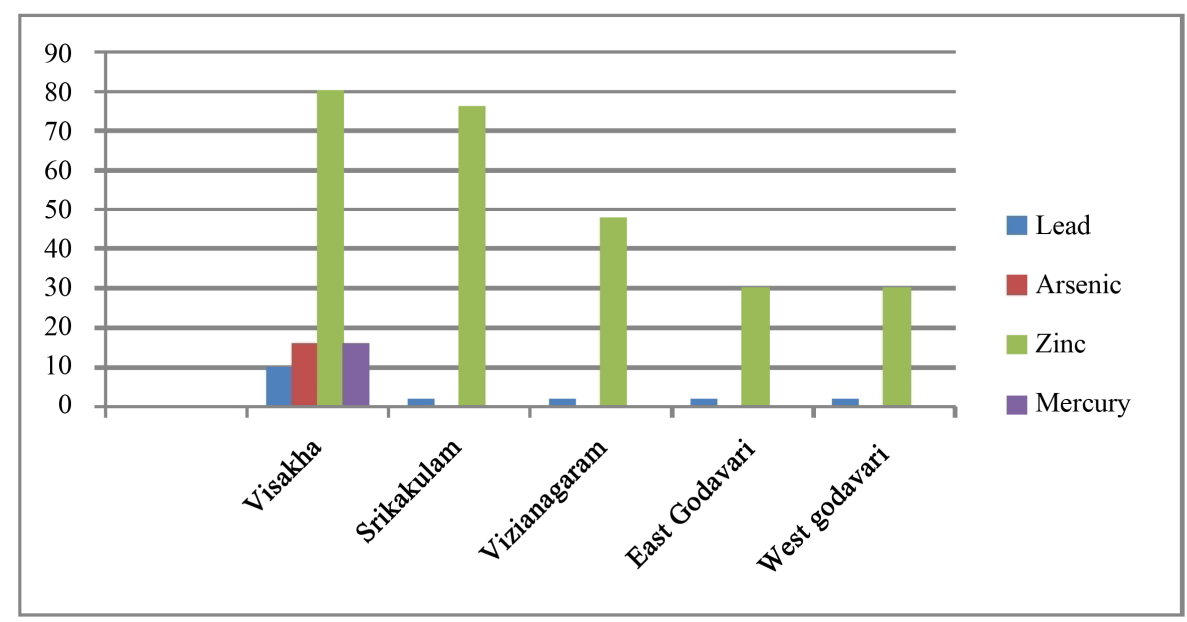

Figure 7. Percent of positive chilled milk samples for heavy metals in different regions.

Chlorane and Methoxchlor were found in $40 \%$ of samples. About $48 \%$ of samples were positive for Endosulfan and $42 \%$ of samples positive for Heptachlor. In Vizianagaram, 38\% of samples were positive for Lindane and Heptachlor. About 36\% of samples were positive for Mehtoxchlor. Endosulfan was found in 46\% of samples and chlorane was found in 34\% of samples. In East Godavari, $48 \%$ of samples contained Lindane, 38\% of samples contained Endosulfan, 34\% of samples contained Chlorane and $28 \%$ and 38\% samples were positive for Heptachlor and Methoxchlor respectively. In West Godavari, 50\% of samples were positive for Lindane and Methoxchlor, Endosulfan was present in $44 \%$ of samples, Chlorane was present in 36\% of samples and $24 \%$ of samples contained Heptachlor.

The pesticide residues found in milk samples, as they are applied as part of agricultural practices to grow fodder for live stock. The milk samples may contain pesticides like organochlorines, organophosphates and carbamates. The pesticide residues in milk samples can be detected by atomic absorption spectrophotometry. The presence of pesticide residues in milk is a potential risk to the cattle as well as humans. These pesticide residue enter in the body and accumulate in the body fat may cause endocrine problems and cancer [22]. The milk samples collected from different live stock were subjected pesticide residue analysis through HPTLC was carried out in Pakistan. Almost 50\% of samples contained pesticide residues and were found to be more than maximum limit [22].

The milk samples were analyzed for presence of DDT (Dichloro dimethyl tetrachloroethane), PCB (polychlorinated biphenyls) and heavy metals like lead and cadmium etc in Poland. These contaminants were determined in milk and dairy products through atomic absorption flame spectrophotometry. The levels of these contami- 
nants were found to be low but cannot be ignored in health point of humans as they are hazardous and may cause cancers [23]. The organophosphates and carbamates were found in milk samples and feed stuff of dairy cattle in Brazil. The pesticide contamination of milk samples mainly occurs through the remnants of pesticides found in animal feed which are secreted later through the milk. The feed stuff of animals, water and finally the milk secreted by the cattle contained the pesticide residues which were detected through the gas chromatography. The presence of residues is considered as risk and cause potential health hazards [24].

The heavy metals like lead, arsenic, zinc and mercury residues were found to occur in raw milk samples. The percentage of samples was shown in Table 9. In Visakhapatnam, about $20 \%$ of raw milk samples were found to contain lead, $40 \%$ samples were positive for arsenic, $80 \%$ samples contained zinc and $20 \%$ of samples contained mercury. In Srikakulam, lead residues were found in $4 \%$ of samples and zinc residues were found in $40 \%$ of samples. Arsenic and mercury residues were absent. In Vizianagaram, 4\% of samples contained lead and 50\% samples were found to have zinc. Arsenic and mercury were absent. In East Godavari lead and zinc residues were found in 2 and 30\% of samples respectively. In West Godavari, the percentage of positive samples was similar to that of results observed in East Godavari district. In vendor's milk samples contained $40 \%$ of lead, $30 \%$ of arsenic, $80 \%$ of zinc and $4 \%$ of mercury residues.

The heavy metals like lead, arsenic, zinc and mercury residues were found to occur in chilled milk samples. The percentage of samples was shown in Table 10. In Visakhapatnam, about $10 \%$ of chilled milk samples were found to contain lead, $16 \%$ samples were positive for arsenic, $80 \%$ samples contained zinc and $16 \%$ of samples contained mercury. In Srikakulam, lead residues were found in $2 \%$ of samples and zinc residues were found in $76 \%$ of samples. Arsenic and mercury residues were absent. In Vizianagaram, 2\% of samples contained lead and $48 \%$ samples were found to have zinc. Arsenic and mercury were absent. In East Godavari lead and zinc residues were found in $2 \%$ and $30 \%$ of samples respectively. In West Godavari, the percentage of positive samples was similar to that of results observed in East Godavari district. In Visakhapatnam, the industrial contaminants majorly zinc was found in high \% of samples because several industries were put up in and surroundings of Visakhapatnam. These industrial contaminants enter the milk supply chain through air and water pollution.

The industrial contaminants in milk in the current study were detected by atomic absorption spectrophotometer. The heavy metals like lead, cadmium, arsenic, tin and zinc occur as environmental contaminants and enter the animal feed stuff or water and thereby into milk samples. The contamination of heavy metals into soil is through industrial and agricultural processes. The heavy metals cannot be metabolized in the body and persist causing toxic effect at cellular and molecular level. These show potential or hazardous effects on cattle and humans increasing the risk of incidence of various cancers. The whole milk powder contained industrial contaminants in intolerable levels in samples analyzed in the Egypt area [25]. In another study the milk samples contained lead, cadmium and zinc more than the permissible levels in Egypt [26].

\section{Conclusions}

The current research study revealed that the hygienic quality of raw milk supplying to dairies, milk sold by vendors directly to consumers in the coastal districts of Andhra Pradesh was found to be poor. It also confirmed that raw milk from producers, vendors and bulk chilling centers may cause serious health hazard to the public because of containing pathogens, antibiotic residues, aflatoxin M1, pesticides and heavy metals exceed the maximum permissible limits and were found to be far above the standards of bureau of Indian standards, international organization for standardization.

The hygienic quality of the milk in this study was found to be poor due to less cleaning and sanitizing of milking and milk storage equipments, poor storage temperature, transportation, long storage periods after milking and poor health conditions of the live stock. Immediate measures are needed to be taken to ensure safety of raw milk in public point of view in Visakhapatnam, East \& West Godavari regions. It suggested that efforts should be made to strengthen the quality control system in the country by creating awareness about public health safety to all the vendors, employees of dairy farms and in public in order to improve milk quality according to FSSAI (Food Safety Standards Authority of India, 2006) [27].

\section{References}

[1] Sheehan, W.J. and Phipatanakul, W. (2009) Tolerance to Water Buffalo Milk in a Child with Cow Allergy. Annals of Allergy, Asthma \& Immunology, 102, 349. http://dx.doi.org/10.1016/S1081-1206(10)60342-0 
[2] Sahai, D. (1996) Buffalo Milk: Chemistry and Processing Technology. Karnal: Shalini International (SI) Publications, India, 132001.

[3] Talpur, F.N., Bhanger, M.I., Khooharo A.A. and Zuhra, M.G. (2008) Seasonal Variation in Fatty Acid Composition of Milk from Ruminants Reared under the Traditional Feeding System of Sindh, Pakistan. Livestock Science, 118, 166172. http://dx.doi.org/10.1016/j.livsci.2008.04.008

[4] Kunz, C., Rudloff, S., Baier, W., Klein, N. and Strobel, S. (2000) Oligosaccharides in Human Milk. Structural, Functional and Metabolic Aspects. Annual Review of Nutrition, 20, 699-722. http://dx.doi.org/10.1146/annurev.nutr.20.1.699

[5] Ahmad, S., Gaucher, I., Rousseau, F., Beaucher, E., Piot, M., Grongnet, J.F. and Gaucheron, F. (2008) Effects of Acidification on Physicochemical Characteristics of Buffalo Milk: A Comparison with Cow's Milk. Food Chemistry, 106, 11-17. http://dx.doi.org/10.1016/j.foodchem.2007.04.021

[6] Ibrahim, E.M., et al. (1983) Seasonal Variation in Fat, Carotene and Vitamin A Contents of Milk from Buffaloes and Cows Herds. Journal of Agricultural Science, 14, 195-206.

[7] Manob kanti, B. (1996) Dairy Co-Operative and Rural Development. Finance India, X, 406-411.

[8] FAO (1990) The Technology of Traditional Milk Production in Developing Countries. FAO Animal Production and Health Papers 85, Rome.

[9] Haridy, M.S.A. (1992) Yeast Flora of Raw Milk in El-Minia City, Egypt. Cryptogamie Mycologie, 13, 321-326.

[10] Uraz, T. (1988) Çig sütlerin bakteriyolojik niteliklerine göre siniflandirilmasi. Gida, 13, 393-397.

[11] Roca-Fernández, A.I. (2011) Sustainable Milk Production Systems in Humid Areas Using Farm Resources. Ph.D. Thesis, Universidad de Santiago de Compostela, Santiago de Compostela.

[12] Van Egmond, H.P. (1989) Current Situation on Regulations for Mycotoxins. Overview of Tolerances and Status of Standard Methods of Sampling and Analysis. Food Additives \& Contaminants, 6, 139-188. http://dx.doi.org/10.1080/02652038909373773

[13] Suliman, S.E. and Abdalla, M.A. (2013) Presence of Aflatoxin M1 in Dairy Cattle Milk in Khatorum State-Sudan. International Journal of Scientific \& Technology Research, 2, 10-12.

[14] Ekici, K., Bozkurt, H. and Isleyici, O. (2004) Isolation of Some Pathogens from Raw Milk of Different Milch Animals. Pakistan Journal of Nutrition, 3, 161-162.

[15] Gwida, M.M. and EL-Gohary, F.A. (2013) Zoonotic Bacterial Pathogens Isolated from Raw Milk with Special Reference to Escherichia coli and Staphylococcus aureus in Dakahlia Governorate, Egypt. 2, 705. http://dx.doi.org/10.4172/scientificreports.705

[16] Saxena, M. and Rai, P. (2013) Microbiological and Chemical Analysis of Raw, Pasteurized and UHT Milk during Preservation in India. International Journal of ChemTech Research, 5, 2804-2809.

[17] Titouche, Y., Hakem, A., Houali, K., Yabrir, B., Malki, O., Chergui, A., Chenouf, N., Yahiaoui, S., Labiad, M., Ghenim, H., Kechih-Bounar, S., Chirila, F., Nadas, G. and Fit, N. (2013) Detection of Antibiotics Residues in Raw Milk Produced in Freha Area (Tizi-Ouzou), Algeria. Bulletin of the University of Agricultural Sciences and Veterinary Medicine Cluj-Napoca Agriculture, 70, 83-87.

[18] Movassagh, M.H. (2011) Study of Antibiotic Residues in Cow Raw Milk by Copan Milk Test in Parsabad reGion, Ardabil Province, Iran. Annals of Biological Research, 2, 355-359. www.scholarsresearchlibrary.com

[19] Forouzan, S., Rahimirad, A., Seyedkhoei, R., Asadzadeh, J. and Bahmani, M. (2014) Determination of Antibiotic Residues in the Pasteurized Milk Produced in West Azerbaijan Province, North West of Iran. Journal of Coastal Life Medicine, 2, 297-301.

[20] Veldman, A., Meijs, J.A.C., Borggreve, G.J. and Heeres van der Tol, J.J. (1992) Carry-Over of Aflatoxin from Cows' Food to Milk. Animal Production, 55, 163-168. http://dx.doi.org/10.1017/S0003356100037417

[21] Zain, M.E. (2011) Impact of Mycotoxins on Humans and Animals. Journal of Saudi Chemical Society, 15, $129-144$. http://dx.doi.org/10.1016/j.jscs.2010.06.006

[22] Shahzadi, N., Imran, M., Sarwar, M., Hashmi, A.S. and Wasim, M. (2013) Identification of Pesticides Residues in Different Samples of Milk. Journal of Agroalimentary Processes and Technologies, 19, 167-172.

[23] Radzymińska, M., Smoczyński, S.S. and Kopeć, M. (2008) Persistent Organochlorine Pesticide Lead, Cadmium, Nitrate (V) and Nitrate (III) in Polish Milk and Dairy Products. Polish Journal of Environmental Studies, 17, 95-100.

[24] Fagnani, R., Beloti, V., Battaglini, A.P.P., Dunga, K. and Tamanini, R. (2011) Organophosphorus and Carbamates Residues in Milk and Feedstuff Supplied to Dairy Cattle. Pesquisa Veterinária Brasileira, 31, 598-602. http://dx.doi.org/10.1590/S0100-736X2011000700009

[25] Abdallah, M.I.M. (2003) A New Trial for Preservation of Raw Cow’s Milk at $30^{\circ} \mathrm{C}$ and $5^{\circ} \mathrm{C}$ Byactivation of the Natu- 
ral Lactoperoxidase System. Researcher of Food Inspection Lab., Damietta Sea’ Port, Animal Health Research Institute, Agricultural Research Center, Giza.

[26] Malhat, F., Hagag, M., Saber, A. and Fayz, A.E. (2012) Contamination of Cows Milk by Heavy Metal in Egypt. Bulletin of Environmental Contamination and Toxicology, 88, 611-613.

[27] FSSAI (2006) Food Safety Standard Act. Food Safety Standard Authorities of India. 